\title{
A Membrane Defect in Cystic Fibrosis: Decreased Red Cell Permeability to Water
}

\author{
WILLIAM R. GALEY, ${ }^{(34)}$ MARY J. GILLON, AND SHIRLEY MURPHY \\ Departments of Physiology [W. R. G., M. J. G.] and Pediatrics [S. M.]. University of New Mexico School of \\ Medicine, Albuquerque, New Mexico, USA
}

\begin{abstract}
Summary
The abnormally high concentrations of electrolytes and organic solutes found in the glandular secretions of individuals with cystic fibrosis may arise from decreased water content rather than perturbed solute transport. Thus, it is possible that the abnormalities insolute concentrations are a result of a reduced water movement into the secretory product. It is our hypothesis that if an abnormality exists in the transport of water across secretory cell membranes, this defect may also be expressed in nonsecretory cell membrane permeability to water. We report here osmotic water permeability measurements on red celts and 11 cystic fibrosis patients ranging in age from 2 to 20 years and eight normal individuals. The mean hydraulic conductivity for the patients of $1.23 \pm 0.13 \mathrm{~cm}^{3} /$ dyne sec is significantly less $(P<0.001)$ than that of normal individuals who have permeabilities of $1.45 \pm 0.11$ $\mathrm{cm}^{3} /$ dyne sec. Analysis showed that the osmotic water permeability correlates well with the Shwachman score $(r=0.76)$. Patients who are in the poorest clinical condition show the lowest hydraulic conductivities.
\end{abstract}

\section{Speculation}

The observation that the osmotic water permeability of red cell membranes is decreased in cystic fibrosis and the correlation of the degree of this water permeability decrease with the clinical severity of the disease opens a potentially important avenue for exploring the nature of the defect in this disease. It is likely that many other cell types of the cystic fibrosis patient show this same defect in membrane permeability which may lead to pathophysiologic expression of the disease. If so, it may be that decreased water permeability of cells is, or is associated with, the basic defect in cystic fibrosis. Further studies are proposed to investigate the nature of this defect and its relevance to the pathogenesis of cystic fibrosis.

Increased levels of electrolytes are found in sweat (7) and other glandular secretions of patients with cystic fibrosis $(31,32)$. To explain these observations, numerous investigators have searched for defects in the membrane transport of ions in cells from patients having this disease. Several early studies reported decreases in the active $\mathrm{Na}^{+}, \mathrm{K}^{+}$, and/or $\mathrm{Ca}^{2+}$ transport (1) abnormalities in the $\mathrm{Na}^{+}, \mathrm{K}^{+}$-dependent and $\mathrm{Ca}^{2+}$-dependent $\mathrm{ATPases}$ in erythrocytes from patients with cystic fibrosis $(5,18)$. However, more recent studies were unable to confirm these observations and concluded that there are neither abnormalities in sodium, potassium, or calcium transport $(10,11,16,25)$ nor the ATPase enzymes which appear to be responsible for the active transport of these ions across cell membranes.

Because the abnormally high concentrations of electrolytes and organic solutes $(8,17,19)$ found in the glandular secretions of individuals with cystic fibrosis may arise from decreased water content (19) as well as perturbed solute transport, it is equally possible that the abnormalities in solute concentrations are a result of a reduced rate of water movement into the secretory product rather than abnormalities in solute transport.

Consistent with this possibility are the observed decreases in the total volume of pancreatic and intestinal secretions $(23,32)$ produced by patients with cystic fibrosis as well as elevated organic solute concentrations in the juices $(8,17,19)$. Indeed, some investigators have suggested that the apparently large quantities of mucus found in the pancreatic ductal system of cystic fibrosis patients result from the production of insufficient volumes of aqueous secretion to wash normal quantities of enzymes and mucus from the pancreatic ducts (19).

Based on this accumulated information, we have studied the osmotic water permeability of erythrocytes from patients with cystic fibrosis. It is our hypothesis that if a generalized abnormality exists in the transport of water across secretory cell membranes of cystic fibrosis patients, this defect might also be expressed in erythrocyte membrane water permeability. It is the osmotic water permeability ( $L p$ ), also called the hydraulic conductivity of the cell membrane, that is the particularly relevant measurement because net water movement into or out of the exocrine ductal systems takes place by osmosis through epithelial tissues (24).

\section{MATERIALS AND METHODS}

The technique we use for measuring $L p$ has been developed in our laboratory (13) and follows the approach of Sha'afi et al. (27). The determination is based on the analysis of the rate of cell volume change (shrinkage) induced by mixing the erythrocytes with a hyperosmotic solution of a nonpermeant solute.

The basic equation which describes the rate of change in red cell volume when placed in such an environment can be described by a modification of the equation of Sha'afi et al. (27) of the form

$$
\frac{d V_{t}}{d t}=\frac{L p A}{R T}\left(C_{i o}\left(\frac{V_{0}}{V_{t}}\right)-C_{m}\right)
$$

where $V_{t}=$ cell volume at time $t: V_{0}=$ cell volume which is involved in osmotic mechanisms before mixing with hypertonic medium (i.e., $\mathrm{V}$ at time $=0$ ); $\mathrm{A}=$ cell surface area, $\mathrm{C}_{\mathrm{io}}=$ osmolality of solution cells are suspended in before mixing; $C_{m}$ $=$ osmolality of solution cells are suspended in after mixing; $\mathbf{R}=$ ideal gas constant; and $\mathrm{T}=$ absolute temperature.

Light scattering by these cells can be shown to be inversely related to cell volume (27), thus, cell volume changes are easily followed, 256 data points being taken in the l-sec experimental period. The $L p$ of red cells is determined from the best fit of the integration of the equation above to the experimental volume versus time data taken by a computer from a stopped flow light scattering spectrophotometer subsequent to mixing of a red cell suspension with a hypertonic solution of $\mathrm{NaCl}$.

We report here osmotic water permeability measurements per- 
formed within $3 \mathrm{hr}$ of collection by venipuncture on red cells from 11 cystic fibrosis patients ranging in age from 2 to 20 years and eight normal control individuals. The severity of the disease in the 11 patients ranged from mild to severe as indicated by their Shwachman indicies (29).

\section{RESULTS}

As is seen in Table 1, the mean hydraulic conductivity for the patients of $1.23 \pm 0.13 \times 10^{-11} \mathrm{~cm}^{3} /$ dyne sec is significantly less $(P<0.001)$ than that of normal individuals having permeability of $1.47 \times 10^{-11} \pm 0.11 \mathrm{~cm}^{3} /$ dyne sec. Although the apparent osmotic water permeability of erythrocytes is effected by perturbation of membrane area, the best data available (9) and our own observations suggest there is no such abnormality in cystic fibrotic red cells. We must consequently conclude that the rate of osmotic water movement across the erythrocyte membrane in individuals with cystic fibrosis is lower than normal individuals.

Further analysis of the red cell membrane $L p$ values for cystic fibrosis patients was carried out in an attempt to correlate the water permeability of patient erythrocytes with clinical expressions of the disease. This analysis showed that the Lp of cystic fibrosis patient red cells correlates well $(r=0.76)$ with the Shwachman score which is a semiquantitative expression of the clinical severity of the disease (29). As can be seen in Figure 1, patients who are in the poorest clinical condition as denoted by low Shwachman scores also show the lowest hydraulic conductivities. On the other hand, the patients least affected by the disease (high Shwachman scores) also have the most normal red cell water permeabilities compared to control individuals.

\section{DISCUSSION}

Although decreased erythrocyte permeability to water has not yet been shown to bear directly on the expression of cystic fibrosis, it may reflect a generalized membrane water permeability decrease which will be seen in other cells of the body. Especially important are epithelial cells which are intimately involved in the production and modification of glandular secretions.

Numerous investigators have reported increased solute concentrations and/or decreased water content of secretions produced by cystic fibrosis patients. For example, DiSant'Agnese and Talamo (8) have reported increased levels of organic as well as inorganic constituents in the saliva of cystic fibrosis patients, and Kopito $e t$ al. (20) showed that the cervical mucoid secretion in patients with cystic fibrosis has only one-fourth to one-third the usual amount of water and fails to show the usual increase in water content at midcycle. Because the perturbations in these secretions can be explained by decreased water content alone, it may be that the decreased penetrability of the epithelial cell membranes to water leads to the production of a more concentrated secretion. Hence, it is possible that all cells in cystic fibrosis patients possess a decreased water permeability, and the decreased water permeability of the red cell membrane is an expression of that generalized defect.

Several possible explanations for this observed functional defect must currently be considered. First, it may be that the decreased

Table 1. Comparison of Lp's of erythrocytes from cystic fibrosis patients and normal individuals

\begin{tabular}{cccc}
\hline Subjects & $\begin{array}{c}\mathrm{Lp}+\mathrm{S} . \mathrm{D} . \\
\left(\times 10^{11} \mathrm{~cm}^{3} /\right. \\
\text { dyne sec })\end{array}$ & $\begin{array}{c}\text { Difference be- } \\
\text { tween } \mathrm{Lp} \text { 's } \\
\left(\times 10^{-11} \mathrm{~cm}^{3} /\right. \\
\text { dyne sec })\end{array}$ & $\begin{array}{c}P \text { of difference } \\
\text { Control-cystic } \\
\text { fibrosis }\end{array}$ \\
\hline $\begin{array}{c}\text { Normal controls } \\
(n=8)\end{array}$ & $1.47 \pm 0.11$ & & \\
$\begin{array}{c}\text { Cystic fibrosis } \\
\text { patients } \\
(n=11)\end{array}$ & $1.23 \pm 0.13$ & 0.24 & $<0.001$ \\
\hline
\end{tabular}

ERYTHROCYTE HYORAULIC CONDUCTIVITIES OF CF PATIENTS AND NORMAL INOIVIDUALS

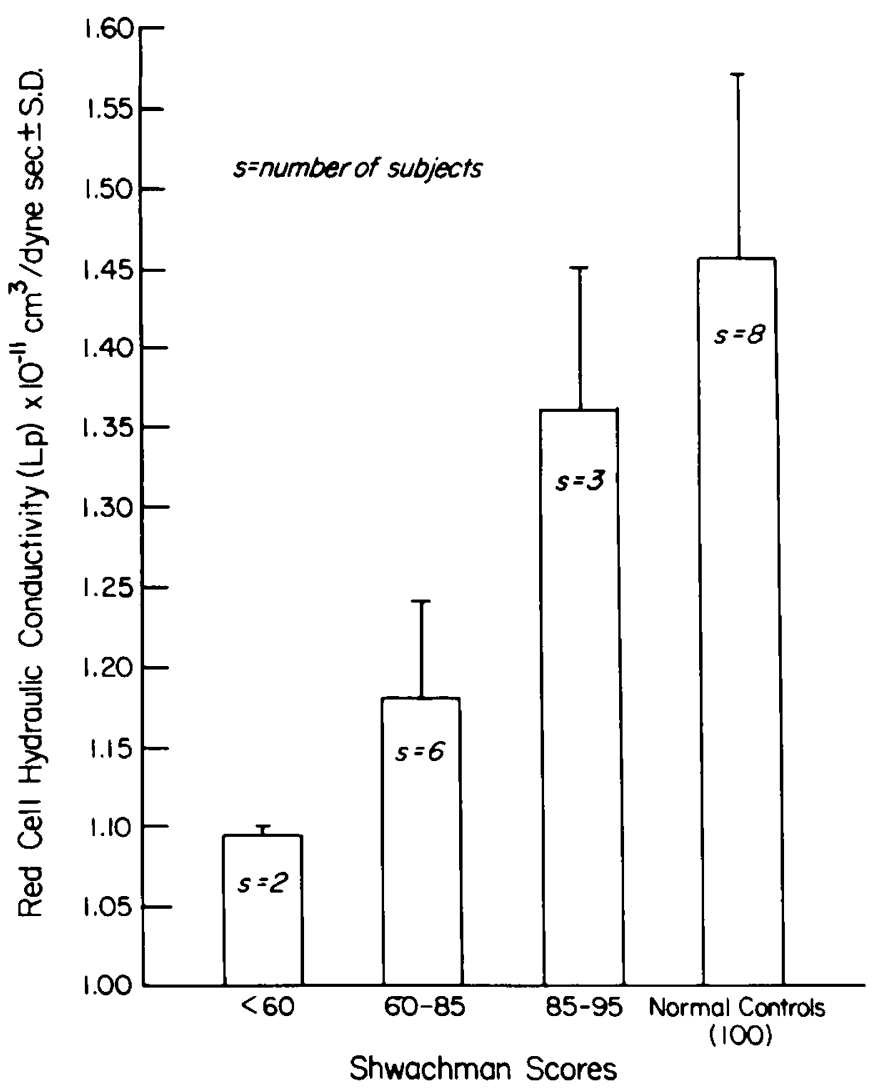

Fig. 1. Relationship of erythrocyte membrane Lp to clinical condition (Schwachman score) of cystic fibrosis patients. Correlation coefficient $(r)$ is 0.76 between individual $\mathrm{Lp}$ values and Shwachman scores. $s$, number of subjects in each group.

water permeability of red cells is an acquired defect due to the compromised nutritional state of the patient. A number of investigators have confirmed a decrease in the amount of certain essential fatty acids in the tissues and serum $(3,21,26,30)$ of patients with the disease. Thus, it is possible that the decrease in these unsaturated fatty acids which tend to "fluidize" cell membranes may lead to a more "solid" and less permeable cell membrane.

However, although the Lp of pure lipid membranes has been shown to be dependent on lipid composition (12), membrane lipid manipulations designed to change red cell fluidity have not resulted in changes of cellular membrane water permeability (28).

It may also be relevant that Chase and Dupont (4) have recently reported that although linoleic acid, the precursor of prostaglandin, is decreased in the red cells and plasma of cystic fibrosis patients, the production of prostaglandin F-2 $\alpha$ is increased in these individuals. This potent vasconstrictor may play a role in decreasing the permeability of the red cell membrane in this disease. Further studies must be conducted to test this possibility, even though there have been no previous reports of such an action for any of the prostaglandins.

Finally, it may be that the decreased water permeability of red cells is the result of a defect in a particular membrane protein associated with water transport. Recent studies by several investigators $(2,6,22)$, have suggested that a particular class, or protein found to span the red cell membrane is responsible for osmotic water permeability.

Indeed, a recent study by our laboratory has strongly suggested that the decreased water permeability seen in red cells of the McLeod phenotype (14) is associated with an abnormality in a 
membrane protein (15). If such an abnormality exists in the cells of individuals with cystic fibrosis, the end result could be a decreased water content of secretions which would result in a thickened and concentrated secretory product. Consequently, the decreased water permeability of cells would play an important role in the expression of cystic fibrosis.

Our current efforts are aimed at elucidating the molecular perturbations which lead to the observations we report here. Clearly, they open the door to new and potentially useful avenues of research into the molecular pathology of cystic fibrosis.

\section{REFERENCES AND NOTES}

1. Balfe, J., Cole, C., and Welt. L. G.: Red cell transport defect in patients with cystic fibrosis and in their parents. Science (Wash. D. C.). 162: 689 (1968).

2. Brown, A. P., Fernstein, M. B., and Shaafi, R. I.: Membrane proteins related to water transport in human erythrocytes. Nature (Lond.). 254: 523 (1975).

3. Campbell. I. M., Crozier, D. N., and Caton, R. B.: Abnormal fatty acid composition and impaired oxygen supply in cystic fibrosis patients. Pediatrics. 57: 480 (1976)

4. Chase, H. P., and Dupont. J.: Abnormal levels of prostaglandins and fatty acids in blood of children with cystic fibrosis. Lancet. 2: 236 (1978).

5. Cole, C. H., and Dirks, J. H.: Changes in erythrocyte membrane APTase in patients with cystic fibrosis of the pancreas. Pediatr. Res.. 6: 616 (1972).

6. Da Silva P. P. Membrane intercalated particles in human erythrocyte ghosts: sites of preferred passage of water molecules at low temperature. Proc. Natl. Acad. Sci. U. S. A.. 70: 1339 (1973).

7. di Sant'Agnese, P. A., Darling, R. C., Perera, G. A., and Shea, E.: Abnormal electrolyte composition of sweat in cystic fibrosis of the pancreas. Pediatrics. 12: 549 (1953).

8. di Sant'Agnese, P. A., and Talamo, R. C.: pathogenesis and pathophysiology of cystic fibrosis of the pancreas. N. Engl. J. Med., 277: 1287 (1967).

9. Emrich, H. M., Heitz, J., Katz. S., and Thom, R.: Cystic fibrosis: normal volumes of red cells. Eur. J. Pediatr., /22: 293 (1976)

10. Feig, S. A., Segel, G. B., and Kern, K. A.: Intrinsic transport function in cystic fibrosis erythrocytes. Clin. Res., 22: 234A, (1974).

11. Feig, S. A., Segel, G. B., Kern, K. A., Osher, A. B., and Schwartz, R. H.: Erythrocyte transport function in cystic fibrosis. Pediatr. Res., 8: 594 (1974).

12. Finkelstein, A., and Cass. A.: Effect of cholesterol on the water permeability of thin lipid membranes. Nature (Lond.), 216: 717 (1967).

13. Galey, W. R.: Determination of human erythrocyte membrane hydraulic conductivity. J. Membr. Sci., 4: 41 (1978),

14. Galey, W. R., Evan, A. P., Van Nice, P. S., Dail, W. G., Wimer, B. M., and Cooper, R. A.: Morphology and physiology of the McLeod erythrocyte. I. Scanning electron microscopy and electrolyte and water transport properties. Vox Sang., 34: 152 (1978).

15. Glaubensklele, C., Evan, A. P.. and Galey, W. R.: Further characterization of the McLeod erythrocyte. Fed. Proc., 38: 1128 (1979).

16. Hadden, J. W., Hansen, L. G.. Shapiro, B. L.. and Warwick. W. J.: Erythrocyte enigmas in cystic fibrosis. Proc. Soc., Exp. Biol. Med., 142: 577 (1973).

17. Hadorn, B., Johansen, P. G.. and Anderson, C. M.: pancreozymin secretion test of exocrine pancreatic function in cystic fibrosis and the significance of the result for the pathogenesis of the disease. Can. Med. Assoc.. J., 98: 377 (1968).

18. Horton, C. R., Cole, W. Q., and Bader, $\mathrm{H}$.: Depressed $\left(\mathrm{Ca}^{++}\right)$transport ATPase in cystic fibrosis erythrocytes. Biochem. Biophys. Res. Commun., 40: 505 (1970).

19. Johansen, P. G.. Anderson, C. M., and Hadorn. B.: Cystic fibrosis of the pancreas: a generalized disturbance of water and electrolyte movement in exocrine tissues. Lancet, l: 455 (1968).

20. Kopito, L. E., Kosasky, H. J., and Shwachman. H.: Water and electrolytes in cervical mucus from patients with cystic fibrosis. Fertil. Steril., 24: 512 (1973).

21. Kuo, P. T., Huang, N. N., and Bassett, D. R.: The fatty acid composition of the serum chylomicrons and adipose tissue of children with cystic fibrosis of the pancreas. J. Pediatr. 60: 394 (1962).

22. Lea, E. J. A., Rich. G. T., and Segrest, J. P.: The effects of the membranepenetrating polypeptide segment of the human erythrocyte $\mathrm{MN}$-glycoprotein on the permeability of model lipid membranes. Biochim. Biophys. Acta, 382: 41 (1975).

23. Mangos, J. A., and McSherry, N. R.: Studies on the mechanism of inhibition of sodium transport in cystic fibrosis of the pancreas. Fed. Res.. 2: 387 (1968).

24. Mauro, A.: Nature of solvent transfer in osmosis. Science (Wash., D. C.) 126 . 252 (1957).

25. McEvoy. F. A., Davies, R.J., Goodchild, M. C., and Anderson, C.M.: Erythrocyte membrane properties in cystic fibrosis. Clin. Chim. Acta. 57: 195 (1974).

26. Rosenlund, M. L., Kim. H. K., and Kritchevsky, D.: Essential fatty acids in cystic fibrosis. Nature (Lond.), 25l: 719 (1974).

27. Sha'afi, R. I., Rich, G. T., Sidel, V. W., Bossert, W., and Solomon. A. K.: The effect of the unstirred layer on human red cell water permeability. J. Gen. Physiol., 50: 1377 (1967).

28. Sha'afi, R. I., Gary-Bobo, C. M., and Solomon. A. K.: Cholesterol effect on hydraulic conductivity of red cell membranes. Biochim. Biophys. Acta, 173: 141 (1969).

29. Shwachman, H., and Kulczycki, L. L.: Long-term study of one hundred five patients with cystic fibrosis. Am. J. Dis. Child., 96: 6 (1958).

30. Underwood. B. A., Denning. C. R., and Navab, M.: Polyunsaturated fatty acids and tocopherol levels in patients with cystic fibrosis. Ann. N. Y. Acad. Sci., 203: 237 (1972).

31. Wiesmann, U. N., Boat. T. F., and di Sant'Agnese, P. A.: Flow-rates and electrolytes in minor-salivary-gland saliva in normal subjects and patients with cystic fibrosis. Lancet, 2: 510 (1972).

32. Zoppi, G., Shmerling, D. H., Gaburro, D., and Prader. A.: The electrolyte and protein contents and outputs in duodenal juice after pancreozymin and secretin stimulation in normal children and in patients with cystic fibrosis. Acta Paediatr. Scand., 59: 692 (1970)

33. Statement concerning human subjects: All procedures reported in this paper have been approved by the University of New Mexico Human Research Review Committee.

34. Requests for reprints should be addressed to: William R. Galey, Department of Physiology. University of New Mexico School of Medicine, Albuquerque. NM 87131 (USA).

35. This research was supported in part by the research grant 5 ROI-AM 17843 from the National Institute of Arthritis. Metabolism and Digestive Diseases and a grant from the National Cystic Fibrosis Foundation.

36. Received for publication May 30. 1979

37. Accepted for publication February 15, 1980 